\title{
Gas Sensors for Monitoring Air Pollution
}

\author{
Kwang Soo Yoo \\ Department of Materials Science and Engineering, University of Seoul, \\ Korea
}

\section{Introduction}

The air pollution caused by exhaust gases from automobiles has become a critical issue. In some regions, fossil fuel combustion is a problem as well. The principal gases that cause air pollution from automobiles are nitrogen oxides, $\mathrm{NO}_{x}\left(\mathrm{NO}\right.$ and $\left.\mathrm{NO}_{2}\right)$, and carbon monoxide (CO). Because $\mathrm{NO}_{x}$ gases with sulfur oxides $\left(\mathrm{SO}_{\mathrm{x}}\right)$ emitted from coal fired plants cause acid rain and global warming and produce ozone $\left(\mathrm{O}_{3}\right)$ that leads to serious metropolitan smog from photochemical reaction, they must be detected and reduced [1-5].

In addition, as greater amounts of oil organic compounds are currently being produced by applied construction materials and households, the number of people who develop various symptoms after moving into a new apartment (e.g., tickle, vertigo, headache, skin trouble) is increasing [6,7]. The principal gases that cause this phenomenon (called "sick-building syndrome") are formaldehyde (HCHO) and volatile organic compounds (VOCs) [8]. Especially, formaldehyde is the most dangerous among indoor pollutants as it could harm all kinds of organisms. Considering these, the allowed concentration of formaldehyde in the Netherlands and Germany is only $0.1 \mathrm{ppm}[9,10]$. Therefore, gas sensors with excellent reactivity and stability are needed.

The first decade of the $21^{\text {st }}$ century has been labeled by some as the "Sensor Decade." A sensor is a device that converts a physical phenomenon into an electrical signal. As such, sensors represent part of the interface between the physical world and the world of electrical devices, such as computers. In recent years, sensors have received people's attention as one of the important devices in electronic systems and enormous capability for information processing has been developed within the electronics industry. Of all sensors, gas sensors and light sensors have been most actively studied [11-13]. The final goal of gas sensor development is to establish the array technology of multifunctional gas sensors that can monitor air pollution with low cost, and is to fabricate the electronic nose using this technology.

Gas sensors are defined as a device that can substitute for human olfaction, and there are many researches being conducted to monitor air pollution by using these gas sensors. Gas sensors can be classified into semiconductor-type, solid electrolyte-type, electrochemicaltype and catalytic combustion-type. Among these, the semiconductor-type gas sensor, the most well-known, is operated by changing its conductivity when it is exposed to gas. The semiconductor-type gas sensor has the advantages of rapid reactivity, efficiency, and gas selectivity when suitable additives are applied to it $[14,15]$. Sensors made of inorganic materials are the most commonly used, especially ceramics. One reason is that many sensors are used in very severe conditions such as high temperature, reactive or corrosive atmosphere and high humidity, and ceramics are most reliable materials in these conditions. Another reason may be that the microstructure of ceramics can be controlled by process 
conditions. In general, electrical, mechanical and optical properties of a material are controlled by changing its composition. In ceramics, however, these properties are also controlled by changing its microstructure [13]. The gas-sensing materials for semiconductortype are $\mathrm{SnO}_{2}, \mathrm{WO}_{3}, \mathrm{In}_{2} \mathrm{O}_{3}$, perovskite-structure oxides, etc., and the electrolyte for solid electrolyte-type gas sensor is $\mathrm{Na}_{3} \mathrm{Zr}_{2} \mathrm{Si}_{2} \mathrm{PO}_{12}[1,2,4,16-19]$.

In this chapter, pollutants and sources of air pollution are briefly explained. Then environmental gas sensors for monitoring air pollution are introduced systematically and the fabrication methods and characteristics of each gas sensor are explained at length with recent research trends.

\section{Air pollution [20]}

Air pollution is the introduction of chemicals, particulate matter, or biological materials that cause harm or discomfort to humans or other living organisms, or cause damage to the natural environment or built environment, into the atmosphere. The atmosphere is a complex dynamic natural gaseous system that is essential to support life on planet Earth. Stratospheric ozone layer depletion due to air pollution has been recognized as a threat to human health as well as to the Earth's ecosystems. Indoor air pollution and urban air quality are listed as two of the world's worst pollution problems in the 2008 Blacksmith Institute World's Worst Polluted Places report [21].

\subsection{Pollutants}

A substance in the air that can cause harm to humans and to the environment is known as an air pollutant. Pollutants can be in the form of solid particles, liquid droplets, or gases. They may be natural or man-made [22]. Pollutants can be classified as primary or secondary. Usually, primary pollutants are directly emitted from a process, such as ashes from a volcanic eruption, the $\mathrm{NO}_{\mathrm{x}}$ and $\mathrm{CO}$ gases from a motor vehicle exhaust or $\mathrm{SO}_{\mathrm{x}}$ released from factories. Secondary pollutants are not emitted directly. Rather, they form in the air when primary pollutants react or interact. An important example of a secondary pollutant is ground level ozone - one of the many secondary pollutants that make up photochemical smog. Some pollutants may be both primary and secondary: that is, they are both emitted directly and formed from other primary pollutants. Causes and effects of air pollution are shown in Fig. 1.

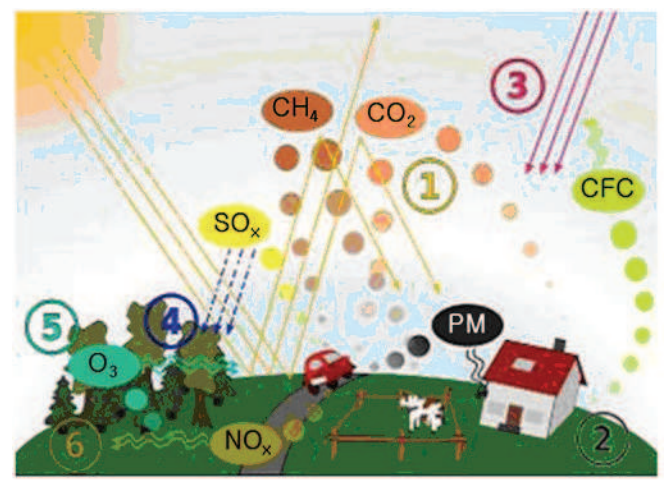

Fig. 1. Schematic drawing, causes and effects of air pollution: (1) greenhouse effect, (2) particulate contamination, (3) increased UV radiation, (4) acid rain, (5) increased ground level ozone concentration, (6) increased levels of nitrogen oxides [20]. 


\subsubsection{Major primary pollutants}

- Nitrogen oxides $\left(\mathrm{NO}_{\mathrm{x}}\right)$ : especially nitrogen dioxide $\left(\mathrm{NO}_{2}\right) \cdot \mathrm{NO}_{2}$ is emitted from high temperature combustion. Can be seen as the brown haze dome above or plume downwind of cities. This reddish-brown toxic gas has a characteristic sharp, biting odor. $\mathrm{NO}_{2}$ is one of the most prominent air pollutants.

- Carbon monoxide (CO): $\mathrm{CO}$ is a colorless, odorless, non-irritating but very poisonous gas. It is a product by incomplete combustion of fuel such as natural gas, coal or wood. Vehicular exhaust is a major source of carbon monoxide.

- Carbon dioxide $\left(\mathrm{CO}_{2}\right): \mathrm{CO}_{2}$ is a colorless, odorless, non-toxic greenhouse gas associated with ocean acidification, emitted from sources such as combustion, cement production, and respiration.

- Volatile organic compounds (VOCs): VOCs are an important outdoor air pollutant. In this field they are often divided into the separate categories of methane $\left(\mathrm{CH}_{4}\right)$ and nonmethane (NMVOCs). $\mathrm{CH} 4$ is an extremely efficient greenhouse gas which enhances global warming. Other hydrocarbon VOCs are also significant greenhouse gases via their role in creating ozone and in prolonging the life of $\mathrm{CH}_{4}$ in the atmosphere, although the effect varies depending on local air quality. Within the NMVOCs, the aromatic compounds such as benzene, toluene and xylene are suspected carcinogens and may lead to leukemia through prolonged exposure. 1,3-butadiene is another dangerous compound which is often associated with industrial uses.

- Formaldehyde ( $\mathrm{HCHO})$ : $\mathrm{HCHO}$ is the most dangerous among the indoor pollutants as it could harm all kinds of organisms. As great amounts of oil organic compounds are induced by applied construction materials and households, $\mathrm{HCHO}$ and VOCs are produced and cause various symptoms (called "sick-building syndrome") after moving into a new apartment [6-8].

- Ammonia $\left(\mathrm{NH}_{3}\right): \mathrm{NH}_{3}$ is emitted from agricultural processes. It is normally encountered as a gas with a characteristic pungent odor. $\mathrm{NH}_{3}$ contributes significantly to the nutritional needs of terrestrial organisms by serving as a precursor to foodstuffs and fertilizers. $\mathrm{NH}_{3}$, either directly or indirectly, is also a building block for the synthesis of many pharmaceuticals. Although in wide use, $\mathrm{NH}_{3}$ is both caustic and hazardous.

- $\quad$ Sulfur oxides $\left(\mathrm{SO}_{\mathrm{x}}\right)$ : especially sulphur dioxide $\left(\mathrm{SO}_{2}\right) \cdot \mathrm{SO}_{2}$ is produced by volcanoes and in various industrial processes. Since coal and petroleum often contain sulphur compounds, their combustion generates $\mathrm{SO}_{2}$. Further oxidation of $\mathrm{SO}_{2}$, usually in the presence of a catalyst such as $\mathrm{NO}_{2}$, forms $\mathrm{H}_{2} \mathrm{SO}_{4}$, and thus acid rain. This is one of the causes for concern over the environmental impact of the use of these fuels as power sources.

- Particulate matter (PM): Particulates, alternatively referred to as PM or fine particles, are tiny particles of solid or liquid suspended in a gas. In contrast, aerosol refers to particles and the gas together. Some particulates occur naturally, originating from volcanoes, dust storms, forest and grassland fires, living vegetation, and sea spray. Human activities, such as the burning of fossil fuels in vehicles, power plants and various industrial processes also generate significant amounts of aerosols. Averaged over the globe, anthropogenic aerosols - those made by human activities - currently account for about 10 percents of the total amount of aerosols in our atmosphere. 
Increased levels of fine particles in the air are linked to health hazards such as heart disease [23], altered lung function and lung cancer.

- Chlorofluorocarbons (CFCs): CFCs are harmful to the ozone layer emitted from products currently banned from use $[24,25]$.

- Persistent free radicals connected to airborne fine particles could cause cardiopulmonary disease.

- Toxic metals, such as lead, cadmium and copper

- Odors such as from garbage, sewage, and industrial processes

- Radioactive pollutants produced by nuclear explosions, war explosives, and natural processes such as the radioactive decay of uranium.

\subsubsection{Secondary pollutants}

- PM formed from gaseous primary pollutants and compounds in photochemical smog: Smog is a kind of air pollution and the word "smog" means a portmanteau of smoke and fog. Classic smog (London type smog) results from large amounts of coal burning in an area caused by a mixture of smoke and sulfur dioxide. Modern smog (photochemical or Los Angeles type smog) does not usually come from coal but from vehicular and industrial emissions that are acted on in the atmosphere by ultraviolet light from the sun to form secondary pollutants that also combine with the primary emissions to form photochemical smog.

- Ground level ozone $\left(\mathrm{O}_{3}\right)$ formed from $\mathrm{NO}_{x}$ and VOCs: $\mathrm{O}_{3}$ is a key constituent of the troposphere. It is also an important constituent of certain regions of the stratosphere commonly known as the Ozone layer. Photochemical and chemical reactions involving it drive many of the chemical processes that occur in the atmosphere by day and by night. At abnormally high concentrations brought about by human activities (largely the combustion of fossil fuel), it is a pollutant, and a constituent of smog.

- $\quad$ Peroxyacetyl nitrate (PAN) similarly formed from $\mathrm{NO}_{x}$ and VOCs.

\subsection{Sources}

Sources of air pollution refer to the various locations, activities or factors which are responsible for the releasing of pollutants into the atmosphere. These sources can be classified into two major categories.

\subsubsection{Anthropogenic sources (human activity)}

- "Stationary Sources" include smoke stacks of power plants, manufacturing facilities (factories) and waste incinerators, as well as furnaces and other types of fuel-burning heating devices.

- $\quad$ "Mobile Sources" include motor vehicles, marine vessels, aircraft and the effect of sound etc.

- Chemicals, dust and controlled burn practices in agriculture and forestry management. Controlled or prescribed burning is a technique sometimes used in forest management, farming, prairie restoration or greenhouse gas abatement. Fire is a natural part of both forest and grassland ecology and controlled fire can be a tool for foresters. Controlled burning stimulates the germination of some desirable forest trees, thus renewing the forest. 
- $\quad$ Fumes from paint, hair spray, varnish, aerosol sprays and other solvents.

- Waste deposition in landfills, which generate methane. Methane is not toxic; however, it is highly flammable and may form explosive mixtures with air. Methane is also an asphyxiant and may displace oxygen in an enclosed space. Asphyxia or suffocation may result if the oxygen concentration is reduced to below $19.5 \%$ by displacement.

- Military, such as nuclear weapons, toxic gases, germ warfare and rocketry.

\subsubsection{Natural sources}

- Dust from natural sources, usually large areas of land with little or no vegetation.

- $\mathrm{CH}_{4}$ gas emitted by the digestion of food by animals, for example, cattle.

- Radon gas from radioactive decay within the Earth's crust. Radon is a colorless, odorless, naturally occurring, radioactive noble gas that is formed from the decay of radium. It is considered to be a health hazard. Radon gas from natural sources can accumulate in buildings, especially in confined areas such as the basement and it is the second most frequent cause of lung cancer, after cigarette smoking.

- Smoke and CO from wildfires.

- Vegetation, in some regions, emits environmentally significant amounts of VOCs on warmer days. These VOCs react with primary anthropogenic pollutants - specifically, $\mathrm{NO}_{x}, \mathrm{SO}_{2}$, and anthropogenic organic carbon compounds - to produce a seasonal haze of secondary pollutants [26].

- Volcanic activity, which produce sulfur, chlorine, and ash particulates.

\section{Environmental gas sensors}

A broad definition of environmental monitoring would include all aspects of air and water quality, soil contamination, electromagnetic radiation, noise, even heat release and light source pollution. However, the major environmental gas sensors are to monitor pollution in air, water, and soil as shown in Table 1 [27]. Environmental standard concentration and threshold limit value for six important gases of air pollution are listed in Table 2 [28,29]. Some information about gas sensors on the base of most familiar metal oxides and technological peculiarities of these sensors fabrication, which can be used for such selection, is presented in Tables 3 and 4 [30]. Gas sensors for monitoring principal gases among air pollutants are described in detail by using typical examples here.

\begin{tabular}{ccccc}
\hline & \multicolumn{2}{c}{ Fixed monitors } & \multicolumn{2}{c}{ Mobile monitors } \\
\cline { 2 - 5 } Stationary source & Ambient & Portable & Personal \\
\multirow{2}{*}{ Air } & $\begin{array}{c}\text { Industrial } \\
\text { emissions, Leaks, } \\
\text { Car exhausts, } \\
\text { Biochemicals }\end{array}$ & Air quality & Air quality, Surveys & Gas alarms \\
& Drinking water, & Water & & \\
Water & Eollution, & Water pollution, & Drinking \\
& Intake & Pollution tracing & water \\
Land & Waste disposal & monitoring & & \\
\hline
\end{tabular}

Table 1. Classification of Environmental Monitoring Applications [27] 


\begin{tabular}{ccccc}
\hline \multirow{2}{*}{ Pollutants } & \multicolumn{3}{c}{ Concentration } & \multirow{2}{*}{ Ref. } \\
\cline { 2 - 4 } & Environmental & $\mathrm{TLV}^{*}$ & Request of sensors & \\
\hline \multirow{2}{*}{$\mathrm{NO}_{x}$} & \multirow{2}{*}{ Below 0.04-0.06 ppm (daily average) } & $\mathrm{NO}_{2}: 3 \mathrm{ppm}$, & $0.01-0.3 \mathrm{ppm}$ & 28 \\
$\mathrm{CO}_{2}$ & - & $5000 \mathrm{ppm}$ & $200-400 \mathrm{ppm}$ & 28 \\
$\mathrm{CO}$ & $35 \mathrm{ppm}^{\dagger}(1 \mathrm{~h}$ average $)$ & $50 \mathrm{ppm}$ & $0.1-10 \mathrm{ppm}$ & $28,+29$ \\
$\mathrm{HCHO}$ & - & $1 \mathrm{ppm}$ & - & 29 \\
$\mathrm{SO}_{2}$ & Below $0.04 \mathrm{ppm}$ (daily average) & $2 \mathrm{ppm}$ & $0-2 \mathrm{ppm}$ & 28 \\
$\mathrm{NH}_{3}$ & - & $25 \mathrm{ppm}$ & - & 28 \\
$\mathrm{O}_{3}$ & Below $0.06 \mathrm{ppm}(1 \mathrm{~h}$ average $)$ & $0.1 \mathrm{ppm}$ & $0-0.5 \mathrm{ppm}$ & 28 \\
$\mathrm{CFC}^{* *}$ & - & - & $20 \mathrm{ppt}$ & 28 \\
\hline
\end{tabular}

*TLV: maximum exposure in $8 \mathrm{~h}$ period in $40 \mathrm{~h}$ work week

${ }^{* *} \mathrm{CFC}$ : Chlorofluorocarbon (Freon)

Table 2. Environmental Standard Concentration and Threshold Limit Value (TLV) of Air Pollution

\begin{tabular}{|c|c|c|}
\hline Materials & Advantages & Disadvantages \\
\hline $\mathrm{SnO}_{2}$ & $\begin{array}{l}\text { High sensitivity, Good stability in } \\
\text { reducing atmosphere }\end{array}$ & $\begin{array}{l}\text { Low selectivity, Dependence on air } \\
\text { humidity }\end{array}$ \\
\hline $\mathrm{WO}_{3}$ & $\begin{array}{l}\text { Good sensitivity to oxidizing } \\
\text { gases, Good thermal stability }\end{array}$ & $\begin{array}{c}\text { Low sensitivity to reducing gases, } \\
\text { Dependence on air humidity, Slow } \\
\text { recovery process }\end{array}$ \\
\hline $\mathrm{Ga}_{2} \mathrm{O}_{3}$ & $\begin{array}{l}\text { High stability, Possibility to } \\
\text { operate at high temperatures }\end{array}$ & Low selectivity, Average sensitivity \\
\hline $\mathrm{In}_{2} \mathrm{O}_{3}$ & $\begin{array}{l}\text { High sensitivity to oxidizing } \\
\text { gases, Fast response and recovery, } \\
\text { Low sensitivity to air humidity }\end{array}$ & $\begin{array}{l}\text { Low stability at low oxygen partial } \\
\text { pressure }\end{array}$ \\
\hline $\begin{array}{c}\mathrm{CTO} \\
\left(\mathrm{CrTiO}_{x}\right) \\
\end{array}$ & $\begin{array}{l}\text { High stability, Low sensitivity to } \\
\text { air humidity }\end{array}$ & Average sensitivity \\
\hline
\end{tabular}

Table 3. Main Advantages and Disadvantages of Well-known Metal Oxides for Gas Sensor Applications [30]

\begin{tabular}{ccccc}
\hline $\begin{array}{c}\text { Metal } \\
\text { oxides }\end{array}$ & Detection gases & $\begin{array}{c}\text { Operating } \\
\text { temperature }\left({ }^{\circ} \mathrm{C}\right)\end{array}$ & Stability & $\begin{array}{c}\text { Compatibility with } \\
\text { IC fabrication }\end{array}$ \\
\hline $\mathrm{SnO}_{2}$ & $\begin{array}{c}\text { Reducing gases } \\
\left(\mathrm{CO}, \mathrm{H}_{2}, \mathrm{CH}_{4}, \text { etc. }\right)\end{array}$ & $200-400$ & Excellent & Imperfect \\
$\mathrm{WO}_{3}$ & $\mathrm{NO}_{x}, \mathrm{O}_{3}, \mathrm{H}_{2} \mathrm{~S}, \mathrm{SO}_{2}$ & $300-500$ & Excellent & Low \\
$\mathrm{Ga}_{2} \mathrm{O}_{3}$ & $\mathrm{O}_{2}, \mathrm{CO}$ & $600-900$ & High & Good \\
$\mathrm{In}_{2} \mathrm{O}_{3}$ & $\mathrm{O}_{3}, \mathrm{NO}_{x}$ & $200-400$ & Moderate & Good \\
$\mathrm{MoO}_{3}$ & $\mathrm{NH}_{3}, \mathrm{NO}_{2}$ & $200-450$ & Moderate & Moderate \\
$\mathrm{TiO}_{2}$ & $\mathrm{O}_{2}, \mathrm{CO}, \mathrm{SO}_{2}$ & $350-800$ & Enhanced & Moderate \\
$\mathrm{ZnO}$ & $\mathrm{CH}_{4}, \mathrm{C}_{4} \mathrm{H}_{10}, \mathrm{O}_{3}, \mathrm{NO}_{\mathrm{x}}$ & $250-350$ & Satisfactory & Good \\
$\mathrm{CTO}$ & $\mathrm{H}_{2} \mathrm{~S}, \mathrm{NH}_{3}, \mathrm{CO}$, volatile & $300-450$ & High & Imperfect \\
& organic compounds & & & Low \\
$\mathrm{Fe}_{2} \mathrm{O}_{3}$ & Alcohol, $\mathrm{CH}_{4}, \mathrm{NO}_{2}$ & $250-450$ & Low & Moderate \\
\hline
\end{tabular}

Table 4. Operating Parameters of Solid-state Gas Sensors on the Base of Metal Oxides and Technological Peculiarities of their Fabrication [30] 


\section{$3.1 \mathrm{NO}_{x}$ gas sensor}

Nitrogen oxide $\left(\mathrm{NO}_{\mathrm{x}}\right)$ sensing materials reported by several investigators are $\mathrm{WO}_{3}, \mathrm{ZnO}$, $\mathrm{SnO}_{2}, \mathrm{In}_{2} \mathrm{O}_{3}, \mathrm{TiO}_{2}$, etc. Among these, $\mathrm{WO}_{3}$ is known as the most promising $\mathrm{NO}_{x}$ gas-sensing material [19,31-39]. These oxides have the advantages of rapid reactivity, efficiency, and gas selectivity when suitable additives are applied to them.

These sensing materials are oxygen-deficient nonstoichiometric compounds. The conductivity of these n-type semiconductors, such as $\mathrm{WO}_{3}$ and $\operatorname{In}_{2} \mathrm{O}_{3}$, is estimated based on the electron created by the surplus metal. When sensing materials are exposed to oxidizing gases at temperature ranging from $200^{\circ} \mathrm{C}$ to $300^{\circ} \mathrm{C}$, the concentration of electrons is decreased due to the reaction between the electron and the gas. Consequently, the conductivity decreases and the resistance increases.

As $\mathrm{NO}_{x}$ is also an oxidizing gas, the concentration of electrons is decreased due to the reaction between the electrons in the sensing materials and $\mathrm{NO}_{x}$ gas, as shown in the following equations:

$$
\begin{aligned}
& \mathrm{NO}+2 e^{-} \longrightarrow \frac{1}{2} \mathrm{~N}_{2}+\mathrm{O}^{2-} \\
& \mathrm{NO}_{2}+2 e^{-} \longrightarrow \mathrm{NO}+\mathrm{O}^{2-}
\end{aligned}
$$

Example [19]:

The powders of various gas-sensing materials were prepared using the solid-state reaction method, starting from the raw materials, $\mathrm{WO}_{3}$ and $\mathrm{In}_{2} \mathrm{O}_{3}$. To improve the reactivity and sensitivity of the gas sensors, $0.1-w t \% \mathrm{PdCl}_{2}$ was added as a catalyst. The powders were mixed, dried at $50^{\circ} \mathrm{C}$, and then calcined at $1000^{\circ} \mathrm{C}$. Thick-film $\mathrm{NO}_{\mathrm{x}}$ gas sensors were prepared on alumina substrate. The $\mathrm{Pt}$ electrodes were also printed with a silkscreen method before the deposition of the $\mathrm{WO}_{3}$ and $\mathrm{In}_{2} \mathrm{O}_{3}$ gas-sensing layer. Schematic diagrams of the sensor are shown in Figure 2. To control the operating temperatures, a printing paste was used to form a Pt heater at the back of the alumina substrate. Pt wires were used as conductuve wires and were attached using silver paste.
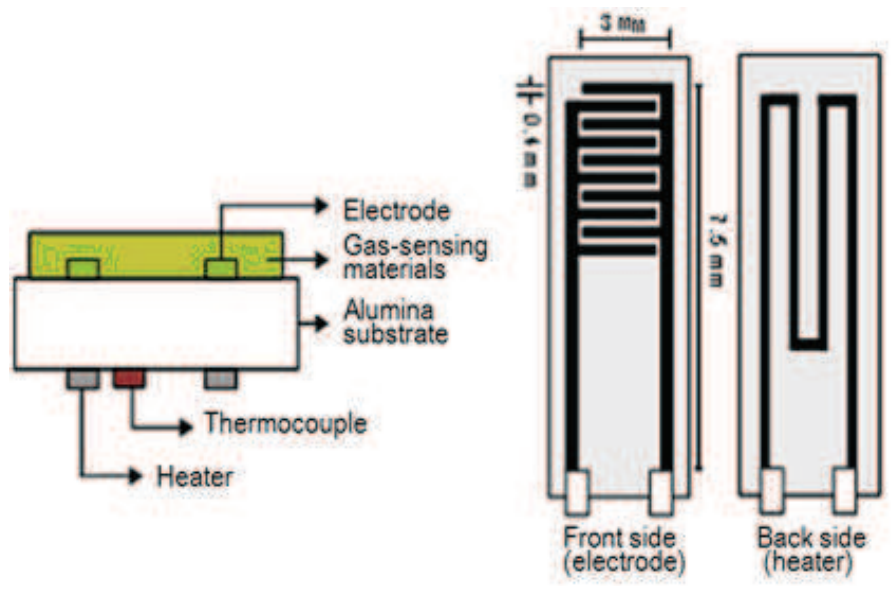

Fig. 2. Schematic diagrams of the gas sensor [19]. 
The gas-sensing properties were measured in a conventional gas-flow apparatus in the range of 1-5-ppm $\mathrm{NO}_{\mathrm{x}}$ by mixing the parent gas (500-ppm $\mathrm{NO}_{\mathrm{x}}$ in an $\mathrm{N}_{2}$ balance) and dry synthetic air. The resistance of the sensor was calculated as:

$$
R_{\mathrm{s}}=R_{L}\left(\frac{V_{C}}{V_{R L}}-1\right)
$$

where $R_{s}$ is the resistance of the sensor, $R_{L}$ is the resistance of the load which was controlled to fix the output voltage to the half of the input voltage because of the change the resistance of the sensor with the change of temperature. $V_{C}$ is the input voltage and $V_{R L}$ is the output voltage. The sensitivity $(S)$, which refers to the resistance of a sensor that has been exposed to $\mathrm{NO}_{x}$ gas versus the resistance of a sensor that has been exposed to air, was calculated as:

$$
S=\left(\frac{R_{g a s}}{R_{a i r}}\right)
$$

where $R_{\text {gas }}$ is the resistance of the sensor that has been exposed to $\mathrm{NO}_{\mathrm{x}}$ gas and $R_{\text {air }}$ is the resistance of the sensor that has been exposed to air. In the gas mixtures of $\mathrm{NO}_{x} /$ air, the $\mathrm{NO}_{\mathrm{x}}$ concentration varied from $1 \mathrm{ppm}$ to $5 \mathrm{ppm}$.

As shown in Figures 3 and 4, when the sensors were exposed to $\mathrm{NO}_{\mathrm{x}}$ gas, their resistance increased. Below $250^{\circ} \mathrm{C}$ the resistance of the $\mathrm{WO}_{3}$ and $\mathrm{In}_{2} \mathrm{O}_{3}$ were very high, so they could not detect the $\mathrm{NO}_{x}$ gas as there were hardly the resistance change of the $\mathrm{WO}_{3}$ and $\mathrm{In}_{2} \mathrm{O}_{3}$. The highest sensitivities of the $\mathrm{In}_{2} \mathrm{O}_{3}$ to $\mathrm{NO}_{x}$ were at $300^{\circ} \mathrm{C}$, as were the highest sensitivities of the $\mathrm{WO}_{3}$ to $\mathrm{NO}$. The highest sensitivities of the $\mathrm{WO}_{3}$ to $\mathrm{NO}_{2}$ were at $250^{\circ} \mathrm{C}$, though.

Comparing the sensing property of $\mathrm{In}_{2} \mathrm{O}_{3}$ with that of $\mathrm{WO}_{3}$, the sensitivities of $\operatorname{In}_{2} \mathrm{O}_{3}$ to $\mathrm{NO}$ were higher than those of $\mathrm{WO}_{3}$ to $\mathrm{NO}$, although they were similar. The highest sensitivity $\left(R_{\text {gas }} / R_{\text {air }}\right)$ of $\operatorname{In}_{2} \mathrm{O}_{3}$ to 5 -ppm NO was 10.22 when it was measured at $300^{\circ} \mathrm{C}$.

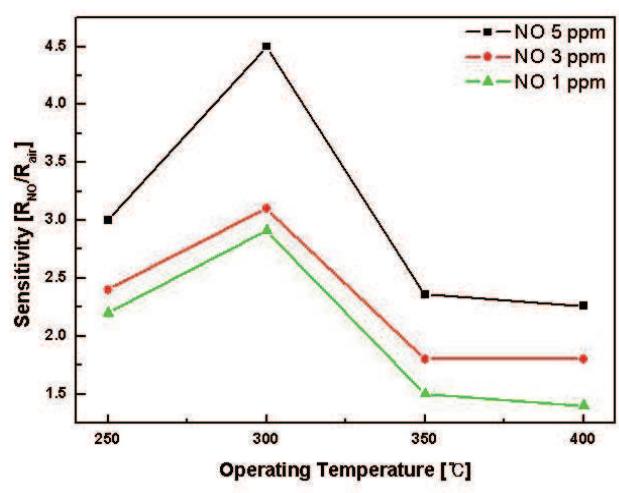

(a) NO gas

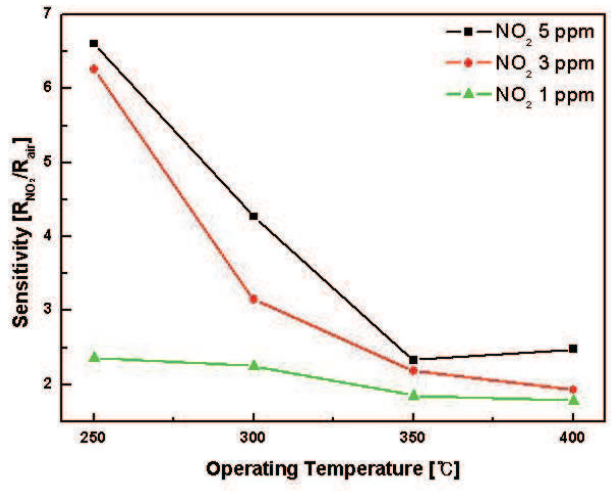

(b) $\mathrm{NO}_{2}$ gas

Fig. 3. $\mathrm{NO}_{x}$ Gas-sensing properites of $\mathrm{WO}_{3}[19]$. 


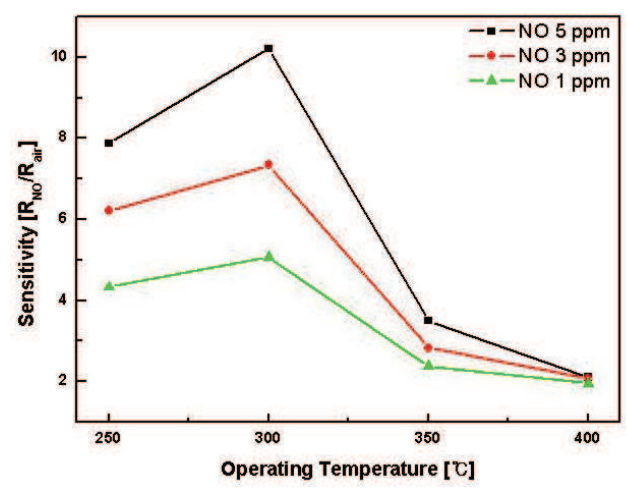

(a) NO gas

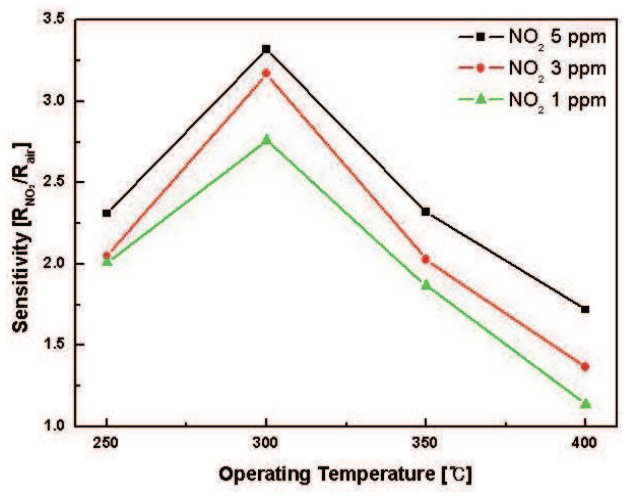

(b) $\mathrm{NO}_{2}$ gas

Fig. 4. $\mathrm{NO}_{x}$ Gas-sensing properites of $\mathrm{In}_{2} \mathrm{O}_{3}[19]$.

\section{$3.2 \mathrm{CO}_{2}$ gas sensor}

Carbon dioxide $\left(\mathrm{CO}_{2}\right)$ sensors have been greatly demanded for monitoring or controlling $\mathrm{CO}_{2}$ in various fields such as combustion process, biology, farming as well as air pollution. So far, many kinds of $\mathrm{CO}_{2}$ sensors using various materials, such as solid electrolyte, mixed oxide capacitors, polymers with carbonate solution and so on, have been investigated [4044]. Among them, solid electrolyte-type $\mathrm{CO}_{2}$ sensors are of particular interest from the viewpoint of low-cost, high-sensitivity, high-selectivity and simple-element structure [45].

Most researches concerning the use of NASICON as active element for gas sensors have been focused on the $\mathrm{Na}_{1+x} \mathrm{Zr}_{2} \mathrm{Si}_{x} \mathrm{P}_{3-\mathrm{x}} \mathrm{O}_{12}$ formula, in the composition range of $1.8<\mathrm{x}<2.4$, because in this range, conductivity shows the largest value [46-48]. A commercial NASICON with a nominal-composition $\mathrm{Na}_{3} \mathrm{Zr}_{2} \mathrm{Si}_{2} \mathrm{PO}_{12}$ has been investigated as a $\mathrm{CO}_{2}$ electrochemical sensor $[49,50]$.

$\mathrm{CO}_{2}$ sensing properties can be upgraded with auxiliary phases in sensing electrodes, which are binary carbonate systems such as $\mathrm{Na}_{2} \mathrm{CO}_{3}-\mathrm{BaCO}_{3}, \mathrm{Na}_{2} \mathrm{CO}_{3}-\mathrm{CaCO}_{3}, \mathrm{Li}_{2} \mathrm{CO}_{3}-\mathrm{BaCO}_{3}$, and $\mathrm{Li}_{2} \mathrm{CO}_{3}-\mathrm{CaCO}_{3}$. The binary systems bring about several advantages such as better long-term stability, quick response time, and resistance to water vapor interruption [18,40,51-54]. The device improved in this way has much increased feasibility in practice [55].

\section{Example [18]}

The NASICON powder was prepared using the sol-gel method, starting from the solutions of $\mathrm{ZrO}\left(\mathrm{NO}_{3}\right)_{2} \cdot 8 \mathrm{H}_{2} \mathrm{O}, \mathrm{NH}_{4} \mathrm{H}_{2} \mathrm{PO}_{4}$, and $\mathrm{Na}_{2} \mathrm{SiO}_{3} \cdot 9 \mathrm{H}_{2} \mathrm{O}$. The solutions were mixed together to form a sol, which was further dehydrated at $80^{\circ} \mathrm{C}$ to form a gel. The gel was then dried at $120^{\circ} \mathrm{C}$ for 8 hours to form a fine dry powder, which was then ground and calcined at $750^{\circ} \mathrm{C}$ to eliminate the organic remains. Afterwards, the calcined material was reground.

The NASICON layer was screen-printed with a paste on the alumina substrate. The Pt electrodes were also screen-printed on the designated regions before and after the deposition of the NASICON layer. The assembly was sintered at $900^{\circ} \mathrm{C}, 1000^{\circ} \mathrm{C}$, and $1100^{\circ} \mathrm{C}$ for 4 hours in air, respectively. After this, a series of auxiliary phases $\left(\mathrm{Na}_{2} \mathrm{CO}_{3}-\mathrm{CaCO}_{3}\right)$ was screen-printed on the Pt sensing electrode. The schematic diagram of the sensor is shown in Figure 5. 

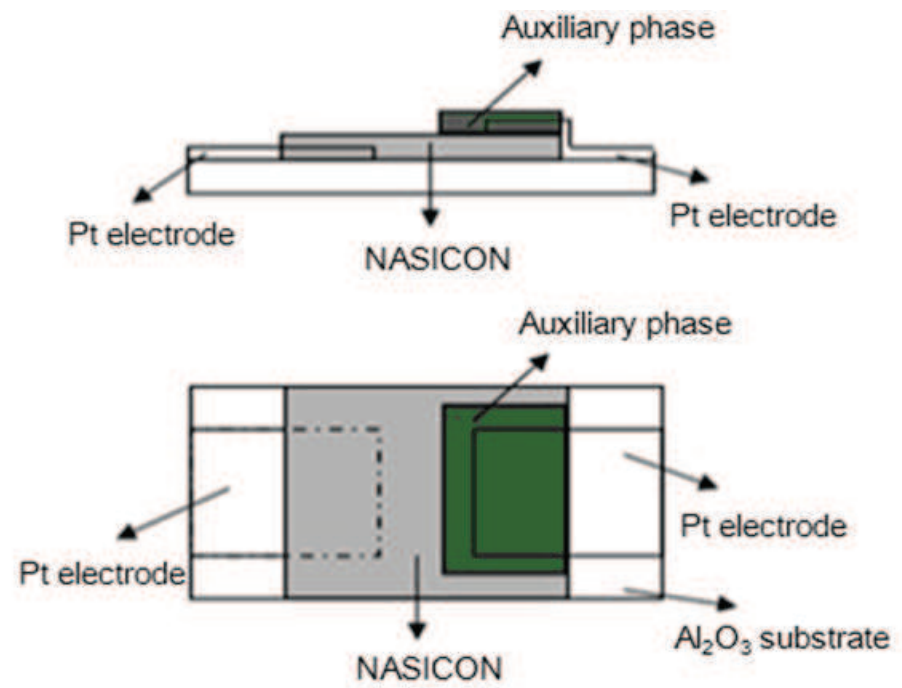

Fig. 5. Schematic diagrams of the $\mathrm{CO}_{2}$ gas sensor [18].
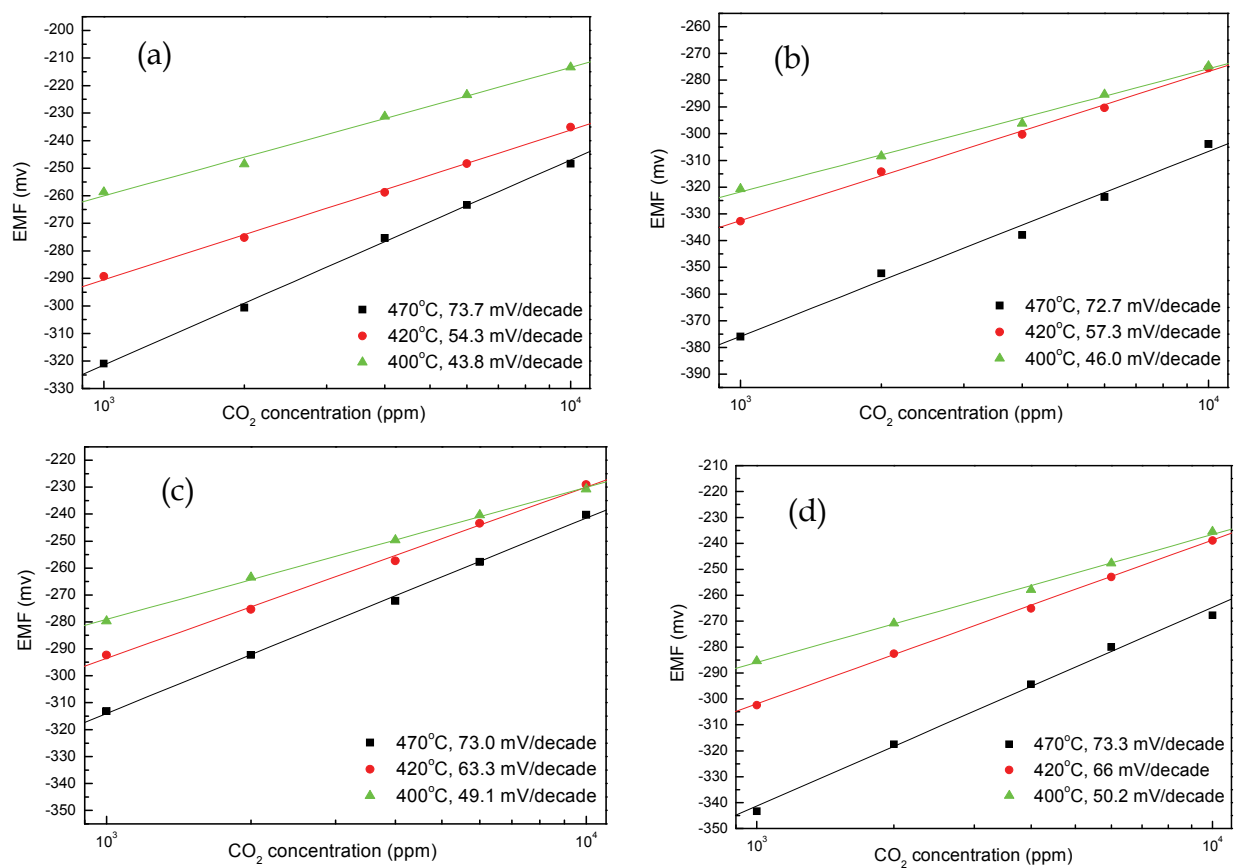

Fig. 6. $\mathrm{CO}_{2}$ concentration vs. EMF for the $\mathrm{CO}_{2}$ gas sensors attached with (a) $\mathrm{Na}_{2} \mathrm{CO}_{3}-\mathrm{CaCO}_{3}$ $=1: 0$, (b) $\mathrm{Na}_{2} \mathrm{CO}_{3}-\mathrm{CaCO}_{3}=1: 0.5$, (c) $\mathrm{Na}_{2} \mathrm{CO}_{3}-\mathrm{CaCO}_{3}=1: 1.5$, and (d) $\mathrm{Na}_{2} \mathrm{CO}_{3}-\mathrm{CaCO}_{3}=1: 2$ [18]. 
Gas-sensing properties were measured in a conventional gas-flow apparatus by changing the mixing ratio between the parent gas $\left(4 \% \mathrm{CO}_{2}\right.$ in an $\mathrm{N}_{2}$ balance) and dry synthetic air. The operating temperature was controlled by monitoring the applied voltage and current using the power supply. The sensors were exposed to the flow $\left(100 \mathrm{~cm}^{3} / \mathrm{min}\right)$ of the required sample gases. The gas mixtures of $\mathrm{CO}_{2} /$ air with the $\mathrm{CO}_{2}$ concentration varied from 1,000 to 10,000 ppm.

Four types of sensors were fabricated from NASICON as a solid electrolyte. A series of $\mathrm{Na}_{2} \mathrm{CO}_{3}-\mathrm{CaCO}_{3}$ mixtures at the molar ratio range of 1:0-1:2 was attached to the sensing electrode. Figure 6 shows the EMF response to $\mathrm{CO}_{2}$ as a function of the $\mathrm{CO}_{2}$ concentration at various temperatures. The EMF variation for each sensor at $470{ }^{\circ} \mathrm{C}$ agreed well with the theoretical value of $74.0 \mathrm{mV} /$ decade, based on a two-electron electrochemical reaction. As the temperature decreased, however, the slope tended to deviate from the ideal. Quite noticeably, the deviation could be suppressed very effectively with $\mathrm{Na}_{2} \mathrm{CO}_{3}-\mathrm{CaCO}_{3}$ (1:2), which allowed $50.2 \mathrm{mV} /$ decade to be kept at temperatures as low as approximately $400^{\circ} \mathrm{C}$. An increase in the amount of $\mathrm{CaCO}_{3}$ at the auxiliary phase is fairly effective for keeping the theoretical value at lower temperatures, whereas an adverse effect occurred when the $\mathrm{CaCO}_{3}$ content was insufficient. The mechanism behind such improvements is not yet well understood, though. It requires further research.

\subsection{HCHO gas sensor}

Formaldehyde $(\mathrm{HCHO})$ is an achromatic toxic gas and has a stimulating scent. When exposed to $\mathrm{HCHO}$ gas even just for a short time, a person may develop headache and vertigo, and when exposed to it for a long time, a person may develop asthma and other lung diseases. When exposed to high concentrations of $\mathrm{HCHO}$, a person may develop pneumonia or edema of the lungs [9]. Considering these, the allowed concentrations of formaldehyde in Korea, Denmark, the Netherlands, and Germany are only 2 ppm, 0.2 ppm, $0.1 \mathrm{ppm}$, and $0.1 \mathrm{ppm}$, respectively [10]. Therefore, gas sensors with excellent reactivity and stability are needed. In view of the above, numerous attempts are being made to reduce the amount of $\mathrm{HCHO}$ in the air. Few studies have been conducted, however, on the detection and the measurement of the amount of $\mathrm{HCHO}$ gas in the air by using ceramic gas sensors.

$\mathrm{HCHO}$ sensing materials are perovskite-structure oxides $\left(\mathrm{ABO}_{3}\right)$ as the semiconductor type. $\mathrm{ABO}_{3}$-type materials have the advantage of high stability. The sensitivity and selectivity of these kinds of sensors can be controlled by selecting suitable $\mathrm{A}$ and $\mathrm{B}$ atoms or through chemical doping with $\mathrm{A}_{1-\mathrm{x}} \mathrm{A}_{\mathrm{x}} \mathrm{B}_{1-\mathrm{y}} \mathrm{B}_{\mathrm{y}} \mathrm{O}_{3}$ materials [56].

$\mathrm{La}_{1-x} \mathrm{Sr}_{x} \mathrm{FeO}_{3}$ ceramics are $\mathrm{ABO}_{3}$ perovskite materials. They are nonstochiometric compounds and p-type semiconductors whose conductivity is estimated through the holes created by the surplus oxygen therein. Substitution at the A-site of an element with a different valence (e.g., the replacement of $\mathrm{La}^{3+}$ by $\mathrm{Sr}^{2+}$ ) leads to the formation of oxygen vacancies and highvalence cations at the B-site, which results in a significant change in the catalytic activity [5760]. When these sensing materials are exposed to reducing gases like $\mathrm{CO}, \mathrm{CH}_{4}$, and $\mathrm{HCHO}$, their conductivity decreases, and their resistance increases because of the chemical surface reactions between the reducing gas and the surplus oxygen [61-63].

\section{Example [17]}

$\mathrm{La}_{1-x} \mathrm{Sr}_{x} \mathrm{FeO}_{3}$ powders $(x=0,0.2,0.5)$ were prepared through the conventional solid-state reaction method, starting from raw materials of $\mathrm{La}_{2} \mathrm{O}_{3}, \mathrm{SrO}$, and $\mathrm{Fe}_{2} \mathrm{O}_{3}$. The mixed powders were dried and were calcined at $1000^{\circ} \mathrm{C}$. 
The $\mathrm{La}_{1-x} \mathrm{Sr}_{x} \mathrm{FeO}_{3}$ sensing layers were silkscreen-printed on the alumina substrate. The $\mathrm{Pt}$ electrodes were also silkscreen-printed on the designated regions before the deposition of the $\mathrm{La}_{1-x} \mathrm{Sr}_{x} \mathrm{FeO}_{3}$ layer. Schematic diagrams of the sensor are shown in Figure 2.

The gas-sensing properties were measured in a conventional gas-flow apparatus by mixing the parent gas (10 to $50 \mathrm{ppm} \mathrm{HCHO}$ in $\mathrm{N}_{2}$ balance) and dry synthetic air. The resistance of the sensor was calculated by using eq. (3). The gas sensitivity, which refers to the resistance of a sensor that has been exposed to $\mathrm{HCHO}$ gas versus the resistance of a sensor that has been exposed to air, was calculated as eq. (4). To confirm the selectivity of the sensors, the gas-sensitivities for $\mathrm{CO}_{2}, \mathrm{~N}_{2}$, and $\mathrm{C}_{3} \mathrm{H}_{8}$ were also measured. The operating temperature was controlled by monitoring the voltage and current applied by using a power supply. The sensors were exposed to a flow $\left(200 \mathrm{~cm}^{3} / \mathrm{min}\right)$ of the required sample gases. Gas mixtures of $\mathrm{HCHO} /$ air with the $\mathrm{HCHO}$ concentration varying from $10 \mathrm{ppm}$ to $50 \mathrm{ppm}$ were used.

As $\mathrm{HCHO}$ gas is a reducing gas, free electrons are released due to the reaction between the surplus oxygen in the sensing materials and the gas [62], as shown in the following equation:

$$
\mathrm{HCHO}_{(g a s)}+\mathrm{O}_{(a d s)}^{2-}=\mathrm{CO}_{2(a d s)}+\mathrm{H}_{2} \mathrm{O}_{(a d s)}+2 e^{-}
$$

The sensing properties were improved by increasing the number of active sites of oxygen through the replacement of La with Sr. As shown in Figs. 7 to 9, when the sensors were exposed to $\mathrm{HCHO}$ gas, their resistance increased. As the reaction yield of the sensing material $\mathrm{La}_{0.8} \mathrm{Sr}_{0.2} \mathrm{FeO}_{3}$ to the gas and the surplus oxygen increased, its sensing property was improved by increasing the resistance rather than the sensing property of $\mathrm{LaFeO}_{3}$. The highest sensitivity $\left(R_{\text {gas }} / R_{\text {air }}\right)$ of $\mathrm{La}_{0.8} \mathrm{Sr}_{0.2} \mathrm{FeO}_{3}$ in $50 \mathrm{ppm}$ was 14.7 when it was measured at $150^{\circ} \mathrm{C}$. The sensing property of $\mathrm{La}_{0.5} \mathrm{Sr}_{0.5} \mathrm{FeO}_{3}$ declined, however, when the amount of surplus oxygen was decreased, despite the fact that the number of active sites of oxygen increased. The reason is assumed to be related to the microstructure of the sensor.

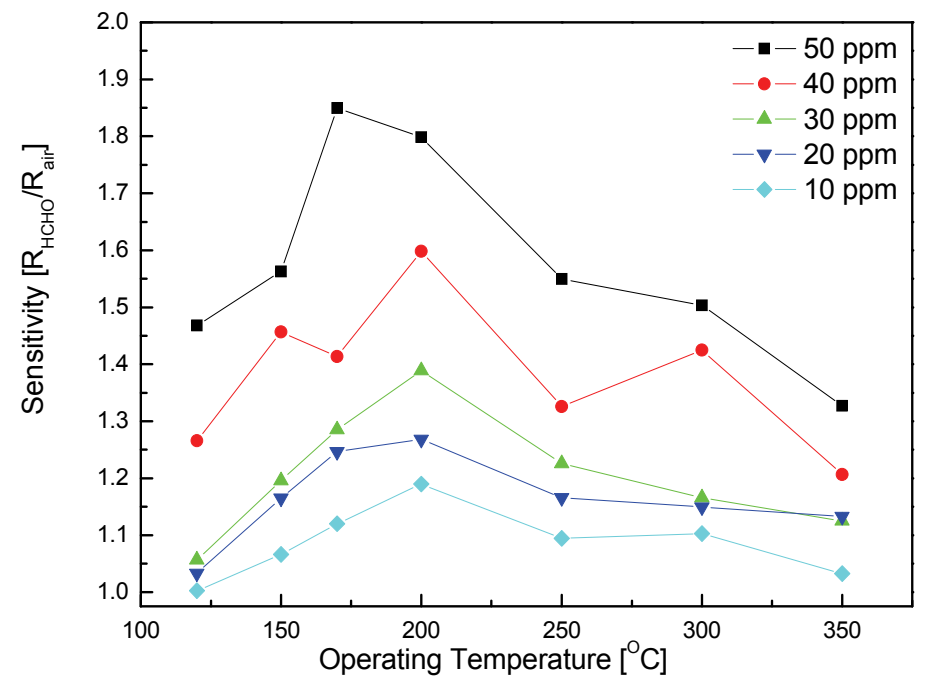

Fig. 7. HCHO Gas-sensing properties of $\mathrm{LaFeO}_{3}$ [17]. 


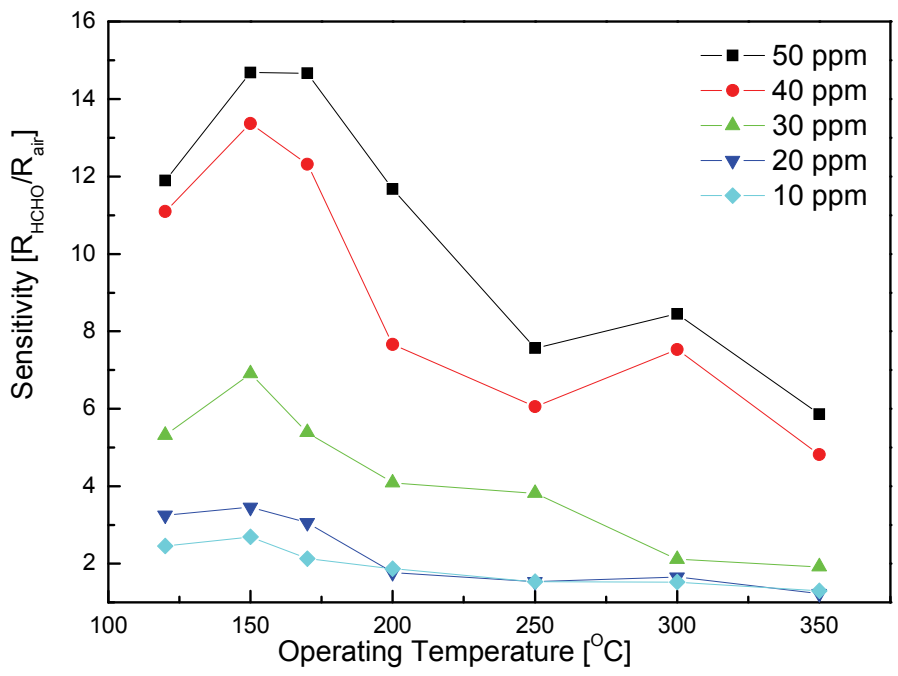

Fig. 8. $\mathrm{HCHO}$ Gas-sensing properties of $\mathrm{La}_{0.8} \mathrm{Sr}_{0.2} \mathrm{FeO}_{3}$ [17].

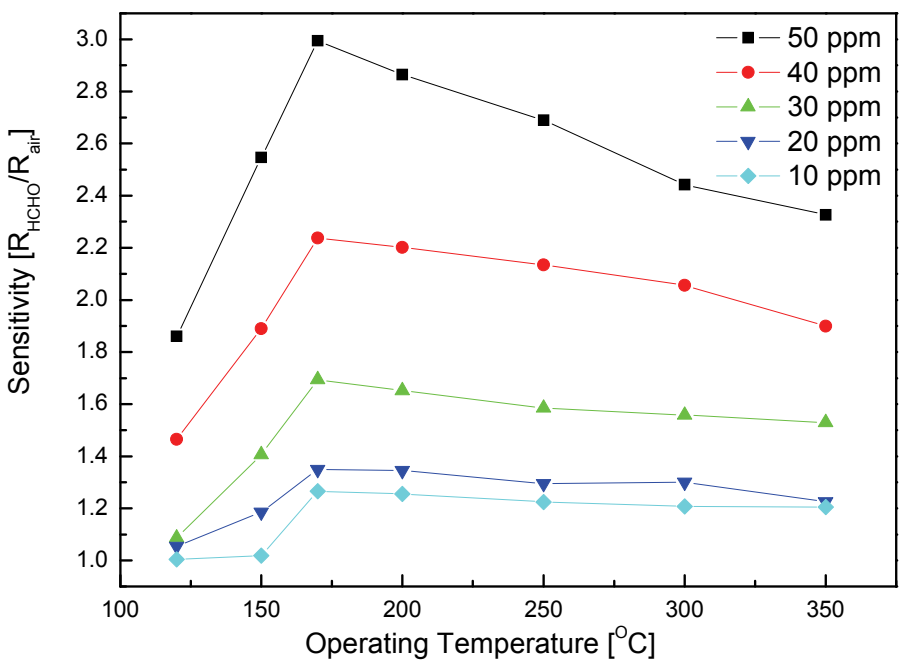

Fig. 9. HCHO Gas-sensing properties of $\mathrm{La}_{0.5} \mathrm{Sr}_{0.5} \mathrm{FeO}_{3}$ [17].

Considering the selectivity of the sensors, as shown in Table 5, the gas-sensitivity for HCHO gas was higher than those for other gases. As $\mathrm{HCHO}$ gas has a very strong reducing property, its sensitivity is over 2.5 because of the reaction between the surplus oxygen in the sensing materials and $\mathrm{HCHO}$ gas. On the other hand, other gases do not react to sensing materials, so their sensitivities were near 1 . In particular, the $\mathrm{La}_{0.8} \mathrm{Sr}_{0.2} \mathrm{FeO}_{3}$ sensor could selectively detect $\mathrm{HCHO}$ gas. 


\begin{tabular}{lccc}
\hline & $R_{3 \% \mathrm{CO}_{2}} / R_{\text {air }}$ & $R_{2000 p p m C_{3} \mathrm{H}_{8}} / R_{\text {air }}$ & $R_{50 p p m H C H O} / R_{\text {air }}$ \\
\hline $\mathrm{LaFeO}_{3}$ & 1.03 & 1.00 & 1.80 \\
$\mathrm{La}_{0.8} \mathrm{Sr}_{0.2} \mathrm{FeO}_{3}$ & 0.89 & 1.07 & 14.7 \\
$\mathrm{La}_{0.5} \mathrm{Sr}_{0.5} \mathrm{FeO}_{3}$ & 0.80 & 0.95 & 2.50 \\
\hline
\end{tabular}

Table 5. Gas Selectivity of the Sensors Measured at $150^{\circ} \mathrm{C}$ [17]

\subsection{Other gas sensors}

\subsubsection{CO gas sensor}

Carbon monoxide (CO) is a colorless, odorless, and tasteless gas which is slightly lighter than air. Because the development of $\mathrm{CO}$ gas sensors was urgent to avoid gas poisoning caused by imperfect combustion of kerosine or gas in a heater, many commercial $\mathrm{SnO}_{2}-$ based sensor devices have been realized by several investigators since 1980's. These gas sensors often operate at high temperature up to $400^{\circ} \mathrm{C}$, in order for high sensitivity.

Recently, in order to decrease the operating temperature, catalysts such as $\mathrm{Pt}, \mathrm{Pd}$, or $\mathrm{Au}[64]$ are added, and metal oxides (e.g. $\mathrm{WO}_{3}, \mathrm{In}_{2} \mathrm{O}_{3}$ [65], $\mathrm{MoO}_{3}$ [66], $\mathrm{V}_{2} \mathrm{O}_{5}$ [67]) are doped into the $\mathrm{SnO}_{2}$ matrix. Especially, mixed oxides, normally tailored by doping metal cations into an oxide matrix, have attracted a great deal of interest in applications from catalysis to gassensing [67].

The electrochemical $\mathrm{CO}$ gas sensor is also useful for a fire alarm. If a sensor could detect $\mathrm{CO}$ in concentrations of 50-100 ppm, it could become a more useful fire detector than the smoke sensor [68].

\subsection{2 $\mathrm{NH}_{3}$ gas sensor}

Ammonia $\left(\mathrm{NH}_{3}\right)$ is extensively used in preparing fertilizers, pharmaceuticals, surfactants, and colorants, with a global production. It presents many hazards to both humans and environment. Detection of $\mathrm{NH}_{3}$ is required in many applications, including leak-detection in air-conditioning systems as well as in sensing of trace amounts of ambient $\mathrm{NH}_{3}$ in air for environmental analysis, breath analysis for medical diagnoses, animal housing, and more [69].

Recently, various $\mathrm{NH}_{3}$ gas sensors based on different sensing mechanisms have been developed. For example, the $\mathrm{WO}_{3}$ nanofibers showed rapid response and recovery characteristics to $\mathrm{NH}_{3}$, and gas-sensing mechanism was explained in terms of surface resistivity and barrier height model [70,71]. It was reported that polypyrrole $(\mathrm{PPy}) / \mathrm{ZnSnO}_{3}$ nanocomposites also exhibited a higher response to $\mathrm{NH}_{3}$ gas [72], and by combining the merits of a chitosan polymer and a porous Si photonic crystal, the optical sensor showed high sensitivity, selectivity, and stability [69].

\subsubsection{Others}

Hydrogen sulfide $\left(\mathrm{H}_{2} \mathrm{~S}\right)$ is a colorless, very poisonous, and flammable gas with the characteristic foul odor of rotten eggs at concentrations up to $100 \mathrm{ppm}$. An ultrahigh sensitive $\mathrm{H}_{2} \mathrm{~S}$ gas sensor was developed utilizing Ag-doped $\mathrm{SnO}_{2}$ thin film on the alumina substrate [73]. This $\mathrm{Ag}-\mathrm{SnO}_{2}$ nanocomposite showed excellent sensing properties upon exposure to $\mathrm{H}_{2} \mathrm{~S}$ as low as $1 \mathrm{ppm}$ at $70^{\circ} \mathrm{C}$. Cuong et. al. [74] reported a solution-processed gas sensor based on vertically aligned $\mathrm{ZnO}$ nanorods on a chemically converted grapheme film. This sensor effectively detected 2 ppm of $\mathrm{H}_{2} \mathrm{~S}$ in oxygen at room temperature. 
In addition, the sulfur dioxide $\left(\mathrm{SO}_{2}\right)$ gas sensor using an alkali metal sulfate-based solid electrolyte [75] and ozone $\left(\mathrm{O}_{3}\right)$ gas sensor of $\mathrm{In}_{2} \mathrm{O}_{3}$ thin-film type [76] were developed.

Recently, gas sensor array for monitoring the perceived car-cabin air quality was reported $[34,77]$. The technological process in microelectromechanical system (MEMS) metal oxide gas sensors in terms of stability and reproducibility has promoted the technology for mass market applications. Tille [34] suggested an automotive air quality gas sensor using microstructured silicon technology as shown in Figure 10. The metallization and the gas-sensing layer were electrically isolated from the heating layer by a passivation. Reducing gases (e.g. $\left.\mathrm{CO}, \mathrm{C}_{\mathrm{x}} \mathrm{H}_{\mathrm{y}}\right)$ result in an increase in conductivity and oxidizing gases (e.g. $\mathrm{NO}_{2}$ ) produce a reduction in the conductivity of the metal oxide. For detection of various gases, several sensor elements such as $\mathrm{SnO}_{2}, \mathrm{ZnO}$, or $\mathrm{WO}_{3}$ could be combined.

(a)

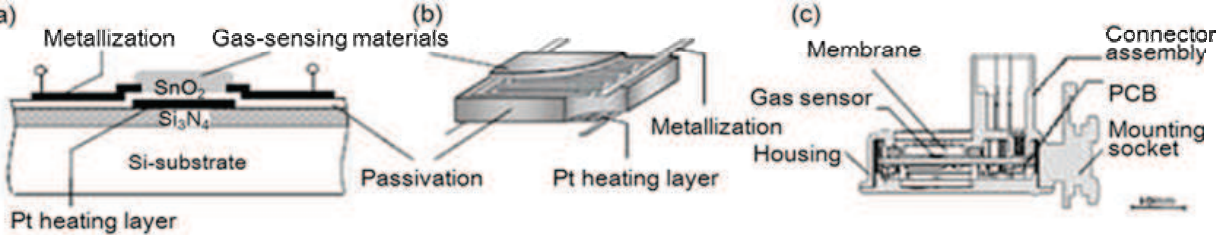

Fig. 10. Schematic illustration of a micro-structured metal oxide gas sensor (a) cross section;

(b) metallization as inter-digital structure, and heating layer as platinum meander structure;

(c) cross section of a typical automotive air quality sensor with embedded metal oxide gas sensor [34].

In the future, smart sensors with high sensitivity, good reliability, and rapid response by using MEMS technology and advanced signal processing should be developed.

\section{References}

[1] H. Kawasaki, T. Ueda, Y. Suda, and T. Ohshima, Sensors and Actuators B, vol. 100, p. 266, 2004

[2] U. Guth and J. Zosel, Ionics, vol. 10, p. 366, 2004.

[3] K. S. Yoo, T. S. Kim, and H. J. Jung, J. Kor. Ceram. Soc., vol. 32, p. 1369, 1995.

[4] D. L. West, F. C. Montgomery, and T. R. Armstrong, Sensors and Actuators B, vol. 106, p. $758,2005$.

[5] Y. S. Yoon, T. S. Kim, and W. K. Choi, J. Kor. Ceram. Soc., vol. 41, p. 97, 2004.

[6] H. S. Kang, S. W. Kim, and Y. J. Cho, J. Kor. Furni. Soc., vol. 18, p. 91, 2007.

[7] J. H. Jang and Y. S. Lee, J. Archi. Ins. Kor., vol. 24, p. 299, 2004.

[8] H. J. An, C. H. Cheong, H. J. Kim, and Y. G. Lee, J. Archi. Ins. Kor., vol. 25, p. 51, 2005.

[9] J. Y. Park and M. S. Jung, J. Soc. Health Edu. Promo., vol. 1, p. 260, 1996.

[10] J. W. Seo, J. Kor. Air-Condi. Refri., vol.31, p. 13, 2002.

[11] Japanese R\&D Trend Analysis Report No. 6: Ceramic Sensors, KRI International, Inc., Tokyo, 1989.

[12] J. S. Wilson, Sensor Technology Handbook, Elsevier, New York, 2005.

[13] S. Y. Yurish and M. T. S. R. Gomes, Smart Sensors and MEMS, Kluwer Academic Publishers, Dordrecht, 2004.

[14] D. D. Lee, Ceramist, vol. 4, p. 57, 2001. 
[15] T. S. Kim, Y. B. Kim, K. S. Yoo, K. S. Sung, and H. J. Jung, J. Kor. Ceram. Soc., vol. 34, p. 387, 1997.

[16] T. G. Nenov and S. P. Yordanov, Ceramic Sensors: Technology and Applications, Technomic Publishing Company, Inc., Lancaster, 1996.

[17] ] M. W. Son, J. B. Choi, H. J. Kim, K. S. Yoo, and S. D. Kim, J. Kor. Phys. Soc., vol. 54, p. $1072,2009$.

[18] H. B. Shim, J. H. Kang, J. W. Choi, and K. S. Yoo, J. Electroceram., vol. 17, p. 971, 2006.

[19] M. W. Son, J. B. Choi, H. I. Hwang, and K. S. Yoo, J. Kor. Sensors Soc., vol. 18, p. 263, 2009.

[20] Wikipedia, http:/ / en.wikipedia.org/wiki/Air_Pollution, 2011.

[21] "Reports", WorstPolluted.org., http://www.worstpolluted.org/. Retrieved 2010-08-29 by Wikipedia.

[22] "EPA: Air Pollutants", http://www.epa.gov/ebtpages/airairpollutants.html. Retrieved 2010-08-29 by Wikipedia.

[23] Evidence Growing of Air Pollution's Link to Heart Disease, Death // American Heart Association, http//www.newsroom.heart.org/index.php?s=43\&item=1029. Retrieved 2010-05-10 by Wikipedia.

[24] "Newly Detected Air Pollutant Mimics Damaging Effects of Cigarette Smoke", http:/ / www.physorg.com/pdf138201201.pdf. Retrieved 2010-08-29 by Wikipedia.

[25] "Infant Inhalation of Ultrafine Air Pollution Linked to Adult Lung Disease", http://www.sciencedaily.com/releases/2009/07/090722123751.htm. Retrieved 2010-08-29 by Wikipedia.

[26] A. H. Goldstein, D. K. Charles, L. H. Colette, and Y. F. Inez, Proc. National Academy of Sci., 2009. http://www.pnas.org/content/106/22/8835.full. Retrieved 2010-12-05 by Wikipedia.

[27] K. W. Jones, in: W. Göpel, J. Hesse, and J. N. Zemel (Ed.), Sensors, vol. 8, Micro- and Nano Sensor Technology/ Trends in Sensor Markets, p. 451, VCH Verlagsgesellschaft mbH, Weinheim, 1995.

[28] K. Colbow and K. L. Colbow, in: W. Göpel, J. Hesse, and J. N. Zemel (Ed.), Sensors, vol. 3, Chemical and Biochemical Sensors Part II, p. 969, VCH Verlagsgesellschaft mbH, Weinheim, 1992.

[29] BITMART, http://www.bitmart.kr/board/view.asp?tb=board_2\&num=49\&page=1\&st $=\& \mathrm{sc}=\& \mathrm{sn}=$, Seoul, Korea, 2009.

[30] G. Korotcenkov, Mater. Sci. E Eng. B, vol. 139, p. 1, 2007.

[31] F. Mitsugi, E. Hiraiwa, T. Ikegami, and K. Ebihara, Surface and Coatings Technology, vol. 169, p. 553, 2003.

[32] H. Kawasaki, J. Namba, K. Iwatsuji, Y. Suda, K. Wada, K. Ebihara, and T. Ohshima, Applied Surface Sci., vol. 197, p. 547, 2002.

[33] C.-Y. lin, Y.-Y. Fang, C.-W. Lin, J. J. Tunney, and K.-C. Ho, Sensors and Actuators B, vol. 146, p. 28, 2010.

[34] T. Tille, Procedia Eng. (Proc. Eurosensors XXIV, Linz, Austria), vol. 5, p. 5, 2010.

[35] L. Bissi, M. Cicioni, P. Placidi, S. Zampolli, I. Elmi, and A. Scorzoni, IEEE Transactions on Instrumentation and Measurement, vol. 60, p. 282, 2011.

[36] A. Serra, M. Re, M. Palmisano, M. V. Antisari, E. Filippo, A. Buccolieri, and D. Manno, , Sensors and Actuators B, vol. 145, p. 794, 2010.

[37] P.-G. Su and T.-T. Pan, Mater. Chem. and Phys., vol. 125, p. 351, 2011. 
[38] U. Lange, V. M. Mirsky, Analytica Chimica Acta, vol. 687, p. 7, 2011.

[39] J. D. Fowler, M. J. Allen, V. C. Tung, Y. Yang, R. B. Kaner, and B. H. Weiller, ACS Nano, vol. 3, p. 301, 2009.

[40] T. Kida, Y. Miyachi, K. Shimanoe, and N. Yamazoe, Sensors and Actuators B, vol. 80, p. 28, 2001.

[41] Y. Miyachi, G. Sakai, K. Shimanoe, and N. Yamazoe, Sensors and Actuators B, vol. 93, p. 250, 2003.

[42] H. J. Kim, H. B. Shim, J. W. Choi, and K. S. Yoo, Proc. 10th Asian Conf. on Solid State Ionics, Kandy, Sri Lanka, p. 849, 2006.

[43] H. J. Kim, J. W. Choi, S. D. Kim, and K. S. Yoo, Mater. Sci. Forum, vols. 544-545, p. 925, 2007.

[44] J. J. Lai, H. F. Liang, Z. L. Peng, X. Yi, and X. F. Zhai, J. Phys.: Conf. Series (3rd Internaional Photonics \& OptoElectronics Meetings), vol. 276, p. 012129, 2011.

[45] F. Qiu, L. Sun, X. Li, M. Hirata, H. Suo, and B. Xu, Sensors and Actuators B, vol. 45, p. 233, 1997.

[46] J. P. Boilot, P. Salanié, G. Desplanches, and D. Le Potier, Mater. Res. Bull., vol. 14, p. 1469, 1979.

[47] D. H. H. Quon, T. A. Wheat, and W. Nesbitt, Mater. Res. Bull., vol. 15, p. 1533, 1980.

[48] G. Desplanches, M. Rigal, and A. Wicker, Am. Ceram. Soc. Bull., vol. 59, p. 546, 1980.

[49] N. Miura, S. Yao, Y. Shimizu, and N. Yamazoe, Sensors and Actuators B, vol. 9, p. 165, 1992.

[50] Y. Sadaoka, Y. Sakai, M. Matsumoto, and T. Manabe, J. Mater. Sci., vol. 28, p. 5783, 1993.

[51] S. Yao, Y. Shimizu, N. Miura, and N. Yamazoe, Chem. Lett., vol. 1990, p. 2033, 1990.

[52] N. Miura, S. Yao, Y. Shimizu, and N. Yamazoe, J. Electrochem. Soc., vol. 139, p. 1384, 1992.

[53] S. Yao, Y. Shimizu, N. Miura, and N. Yamazoe, Jpn. J. Appl. Phys., vol. 31, p. L197, 1992.

[54] Y. Shimizu, and N. Yamashita, Sensors and Actuators B, vol. 64, p. 102, 2000.

[55] T. Kida, H. Kawate, K. Shimanoe, N. Miura, and N. Yamazoe, Solid State Ionics, vol. 136, p. $647,2000$.

[56] S. Zhao, J. K. O. Sin, B. Xu, M. Zhao, Z. Peng, and H. Cai., Sensors and Actuators B, vol. 64, p. 83, 2000.

[57] V. Lantto, S. Saukko, N. N. Toan, L. F. Reyes, and C. G. Granqvist, J. Electroceram., vol. 13, p. 721, 1992.

[58] I. Waernhus, N. Sakai, H. Yokokawa, T. Grande, M. Einarsrud, and K. Wiik, Solid State Ionics, vol. 178, p. 907, 2007.

[59] M. Popa, J. Frantti, and M. Kakihana, Solid State Ionics, vols. 154 - 155, p. 437, 2002.

[60] H. K. Hong, B. H. Kim, Y. I. Cheon, and Y. K. Sung, J. Kor. Elect. Eng., vol. 13, p. 372, 1990.

[61] N. N. Toan, S. Saukko, and V. Lantoo, Physica B, vol. 327, p. 297, 2003.

[62] Z. Zhong, K. Chen, Y. Ji, and Q. Yan, Appl. Catalysis A : General, vol. 156, p. 29, 1997.

[63] S.-D. kim, B.-J. kim, J.-H. Yoon, and J.-S. Kim, J. Kor. Phys. Soc., vol. 51, p. 2069, 2007.

[64] B. Bahrami, A. Khodadadi, M. Kazemeini, and Y. Mortazavi, Sensors and Actuators B, vol. 133, p. 352, 2008.

[65] M. W. Son, J. B. Choi, H. I. Hwang, and K. S. Yoo, J. Kor. Sensors Soc., vol. 18, p. 263, 2009. 
[66] Z. A. Ansari, S. G. Ansari, T. Ko, and J.-H. Oh, , Sensors and Actuators B, vol. 87, p. 105, 2002.

[67] C.-T. Wang and M.-T. Chen, Sensors and Actuators B, vol. 150, p. 360, 2010.

[68] T. Fujioka, S. Kusanagi, N. Yamaga, Y. Watabe, K. Doi, T. Inoue, T. Hatai, K. Sato, A. Takemoto, and D. Kouzeki, in: M. Aizawa (ed.), Chemical Sensor Technology, vol. 5, p. 65, Kodansha Ltd., Tokyo, 1994.

[69] Y. Shang, X. Wang, E. Xu, C. Tong, and J. Wu, Analytica Chimica Acta, vol. 685, p. 58, 2011.

[70] J.-Y. Leng, X.-J. Xu, N. Lv, H.-T. Fan, and T. Zhang, J. Colloid \& Interface Sci., vol. 356, p. 54, 2011.

[71] N. V. Hieu, V. V. Quang, N. D. Hoa, and D. Kim, Current Appl. Phys., vol. 11, p. 657, 2011.

[72] P. Song, Q. Wang, and Z. Yang, Mater. Letters, vol. 65, p. 430, 2011.

[73] J. Gong, Q. Chen, M.-R. Lian, N.-C. Liu, R. G. Stevenson, and F. Adami, Sensors and Actuators B, vol. 114, p. 32, 2006.

[74] T. V. Cuong, V. H. Pham, J. S. Chung, E. W. Shin, D. H. Yoo, S. H. Hahn, J. S. Huh, G. H. Rue, E. J. Kim, S. H. Hur, and P. A. Kohl, Mater. Letters, vol. 64, p. 2479, 2010.

[75] G.-Y. Adachi and N. Imanaka, in: N. Yamazoe (ed.), Chemical Sensor Technology, vol. 3, p. 131, Kodansha Ltd., Tokyo, 1991.

[76] T. Takada, in: T. Seiyama (ed.), Chemical Sensor Technology, vol. 2, p. 59, Kodansha Ltd., Tokyo, 1989.

[77] M. Blaschke, T. Tille, P. Robertson, S. Maier, U. Weimar, and H. Ulmer, IEEE Sensors J., vol. 6, p. 1298, 2006. 


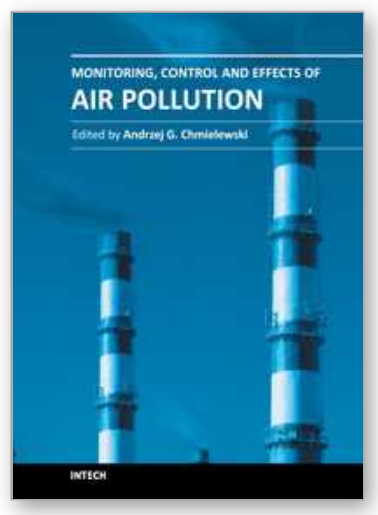

\author{
Monitoring, Control and Effects of Air Pollution \\ Edited by Prof. Andrzej G. Chmielewski
}

ISBN 978-953-307-526-6

Hard cover, 254 pages

Publisher InTech

Published online 23, August, 2011

Published in print edition August, 2011

The book addresses the subjects related to the selected aspects of pollutants emission, monitoring and their effects. The most of recent publications concentrated on the review of the pollutants emissions from industry, especially power sector. In this one emissions from opencast mining and transport are addressed as well. Beside of SOx and NOx emissions, small particles and other pollutants (e.g. VOC, ammonia) have adverse effect on environment and human being. The natural emissions (e.g. from volcanoes) has contribution to the pollutants concentration and atmospheric chemistry governs speciation of pollutants, as in the case of secondary acidification. The methods of ambient air pollution monitoring based on modern instrumentation allow the verification of dispersion models and balancing of mass emissions. The comfort of everyday humanâ $€^{\mathrm{TM}} \mathrm{S}$ activity is influenced by indoor and public transport vehicles interior air contamination, which is effected even by the professional appliances operation. The outdoor pollution leads to cultural heritage objects deterioration, the mechanism are studied and the methods of rehabilitation developed. However to prevent emissions the new technologies are being developed, the new class of these technologies are plasma processes, which are briefly reviewed at the final part of the book.

\title{
How to reference
}

In order to correctly reference this scholarly work, feel free to copy and paste the following:

Kwang Soo Yoo (2011). Gas Sensors for Monitoring Air Pollution, Monitoring, Control and Effects of Air Pollution, Prof. Andrzej G. Chmielewski (Ed.), ISBN: 978-953-307-526-6, InTech, Available from: http://www.intechopen.com/books/monitoring-control-and-effects-of-air-pollution/gas-sensors-for-monitoringair-pollution

\section{INTECH}

open science | open minds

\section{InTech Europe}

University Campus STeP Ri

Slavka Krautzeka 83/A

51000 Rijeka, Croatia

Phone: +385 (51) 770447

Fax: +385 (51) 686166

www.intechopen.com

\section{InTech China}

Unit 405, Office Block, Hotel Equatorial Shanghai

No.65, Yan An Road (West), Shanghai, 200040, China

中国上海市延安西路65号上海国际贵都大饭店办公楼405单元

Phone: +86-21-62489820

Fax: +86-21-62489821 
(C) 2011 The Author(s). Licensee IntechOpen. This chapter is distributed under the terms of the Creative Commons Attribution-NonCommercialShareAlike-3.0 License, which permits use, distribution and reproduction for non-commercial purposes, provided the original is properly cited and derivative works building on this content are distributed under the same license. 